T.Ia. Datsko, V.I. Zelentsov

\title{
EFFECT OF MICROSTRUCTURE OF MODIFIED DIATOMITE ON ITS ADSORPTION PROPERTIES
}

\author{
The Institute of Applied Physics of the Academy of Sciences of Moldova, \\ Academiei Str. 5, Chisinau, MD 2028, Republic of Moldova, E-mail: datsko.tatiana@yandex.ru
}

The effect of microstructural changes caused by chemical modification of diatomite with aluminosilicate nanoparticles on its adsorption properties with respect to fluorine has been elucidated.

The surface modification of diatomite with aluminosilicate is accompanied with significant changes in its structure and chemical properties - a growth of specific surface area, a shift of electrosuperficial properties and an increase of adsorption capacity for fluorine. Moreover, some kind of synergism takes place after modification: adsorption capacity of aluminosilicate species grafted on the diatomite surface is higher than that of bulk aluminosilicate.

The surface-chemical modification of diatomite has been carried out by heating it in a $\mathrm{NaOH}$ solution and subsequent treatment with a solution of aluminum salt and after that with ammonia. Amorphous surface silica partially dissolves during the treatment with $\mathrm{NaOH}$ and due to addition of an aluminum salt it forms an aluminosilicate compound. The obtained product is further denoted as DMA.

The increase in the specific surface area of DMA is connected with variation of the ratio of the micro- and mesopores through the filling of the large mesopores with aluminosilicate and its own microporous structure increment; the specific surface area gets $81.8 \mathrm{~m}^{2} / \mathrm{g}$, which is 2.5 times larger than the corresponding value of the initial unprocessed diatomite $\left(37.5 \mathrm{~m}^{2} / \mathrm{g}\right)$. Partial substitution of Si atoms in silicates of diatomite surface by Al atoms creates as a result of their different valences an excess negative charge, and $\mathrm{pH}_{P Z C}$ of the sorbent surface shifts to higher values compared to initial diatomite sample that facilitates the attraction of more negatively charged ions from solution. Both these phenomena lead to that adsorption capacity of modified diatomite (DMA) with respect to fluorine is considerably increased from 10 to $58 \mathrm{mmol} / \mathrm{g}$.

Aluminosilicate in the DMA composition has 1.3 times greater adsorption capacity with respect to fluorine compared to bulk synthetic aluminosilicate. Since the reactive sites responsible for the adsorption are essentially surface aluminum ions, it is expected that their concentration is closely associated with the content of $\mathrm{Al}_{2} \mathrm{O}_{3}$ in aluminosilicate. It is easy to understand that not all the silica in diatomite matrix, but the surface only was subjected to the substitution of Si atoms with Al, so the surface aluminosilicate composition must contain the increased ratio of $\mathrm{Al}_{2} \mathrm{O}_{3} / \mathrm{SiO}_{2}$; it is 0.5 according to some calculation compared to the volume ratio which is 0.33 ; besides, the surface aluminosilicate is more or less uniformly distributed on the pore material surface, so more aluminum sites are accessible for interaction with fluoride ions. Furthermore, molecular aluminum and silicon precursors are preferentially grafted on sites that enable the formation of Al(IV) coordination form, and deposited aluminum species on silica are Al(IV) tetrahedrally coordinated species. This specific surface site connectivity eventually enables the formation of Brønsted acid sites. Such acid sites may be formulated as bridging hydroxyls in connection with $\mathrm{Al}(\mathrm{IV})$ species, such as pseudo-bridging silanol in $\mathrm{Al} / \mathrm{SiO}_{2}$, therefore more fluorine is involved in complexes with Al.

Apparently, all of the above facts together should be responsible for an increased adsorption capacity of the surface aluminosilicate in the DMA composition.

Keywords: diatomite, chemical-structural modification, nano-sized aluminosilicate, fluorine, adsorption 


\section{ABBREVIATIONS}

$S_{\mathrm{sp}}-$ specific surface area, $\mathrm{m}^{2} / \mathrm{g}$;

$V_{\mathrm{S}}-$ sorption pore volume, $\mathrm{cm}^{3} / \mathrm{g}$;

$V_{\mathrm{me}}-$ the volume of mesopores, $\mathrm{cm}^{3} / \mathrm{g}$;

$V_{\mathrm{mi}}$ - the volume of micropores, $\mathrm{cm}^{3} / \mathrm{g}$;

$a$-adsorption value, $\mathrm{mmol} / \mathrm{g}$;

$a_{\mathrm{m}}-$ adsorption capacity of a sorbent, $\mathrm{mmol} / \mathrm{g}$.

\section{INTRODUCTION}

Due to the high toxicity of fluorine for humans [1], in recent years more attention is paid to the search for low-cost and effective ways to remove it from drinking water [2]. Adsorption of fluorine on natural adsorbents is one of the most attractive methods for its removing from the point of view of the process cheapness and from the viewpoint of formation of non-toxic waste which may be used as building materials, road surface, etc. [3,4]. In recent years, a considerable amount of work has been done on impregnation of natural adsorbents with chemicals to improve their adsorption capacity and hence the removal efficiency [5-7].

The authors of the present paper have reported earlier the sorption behavior of fluoride on alumina [8] and other oxides [9]. We have tested some natural adsorbents as well as chemically modified ones [10] for fluorine removal.

A new sorbent has been synthesized on the base of local diatomite (D1) and aluminosilicate (DMA) having high adsorption capacities with respect to fluorine [11]. We found that DMA performed better as compared to natural diatomite for defluoridation of water. It has been observed that up to $58 \mathrm{mmol}$ of fluoride/g of the sorbent can be removed by DMA from the solutions with initial fluorine concentration up to $0.3 \mathrm{M}$, while the initial unprocessed diatomite has adsorption capacity of about $10 \mathrm{mmol} \mathrm{F/g}$ [12].

An interesting fact was also noticed when studying the adsorption process on DMA - the increase of fluorine adsorption by the aluminosilicate grafted on the diatomite surface compared with bulk synthetic aluminosilicate.

In this report we decided to clarify what has caused this phenomenon, i.e. the effect of microstructure changes in the adsorbent structure due to chemical modification, on its adsorption behavior with respect to fluorine.

\section{PREPARATION OF DMA}

The surface modification of diatomite has been carried out by heating it in a $\mathrm{NaOH}$ solution and its subsequent treatment with a solution of aluminum salt and ammonia. The amorphous surface silica partially dissolves during the treatment with $\mathrm{NaOH}$ and forms an aluminosilicate compound due to addition of an aluminum salt.

In Table 1 the compositions of initial (D1) and modified (DMA) samples of diatomite are shown.

In Table 2 some adsorption-structural properties of unprocessed (D1), modified with aluminosilicate (DMA) samples of diatomite, and of synthetic aluminosilicate (SAS) are presented.

A synthetic aluminosilicate (SAS) with the same $\mathrm{Al}_{2} \mathrm{O}_{3} / \mathrm{SiO}_{2}$ molar ratio was prepared in the following manner: $0.035 \mathrm{M} \mathrm{Na}_{2} \mathrm{SiO}_{3} \cdot 9 \mathrm{H}_{2} \mathrm{O}$ and $6 \mathrm{M}$ $\mathrm{NaOH}$ solutions were added to a $1.7 \mathrm{M}$ $\mathrm{Al}\left(\mathrm{NO}_{3}\right)_{3} \cdot 9 \mathrm{H}_{2} \mathrm{O}$ solution. The resulted DMA with molar ratio $\mathrm{Al}_{2} \mathrm{O}_{3} / \mathrm{SiO}_{2}=0.33$ with the aluminosilicate individual particle range of about $30 \mathrm{~nm}$, deposited both on the surface of the diatomite and on the inner surface of the macro- and larger mesopores $(r>10 \mathrm{~nm})$, partially blocking them.

Table 1. Chemical composition of diatomite before and after modification

\begin{tabular}{cccccccc}
\hline \multirow{2}{*}{ Sample } & \multicolumn{6}{c}{ Composition, $\%$} & Calcination \\
\cline { 2 - 7 } & $\mathbf{S i O}_{\mathbf{2}}$ & $\mathbf{A l}_{\mathbf{2}} \mathbf{O}_{\mathbf{3}}$ & $\mathbf{F e}_{\mathbf{2}} \mathbf{O}_{\mathbf{3}}$ & $\mathbf{C a O}$ & $\mathbf{M g O}$ & $\mathbf{N a}_{\mathbf{2}} \mathbf{O}+\mathbf{K}_{\mathbf{2}} \mathbf{O}$ & loss, \% \\
\hline D1 & 59.7 & 1.31 & 1.28 & 12.8 & 0.69 & 0.34 & 18.5 \\
DMA & 35.5 & 18.9 & 1.33 & 9.0 & 9.02 & 1.30 & 10.3 \\
\hline
\end{tabular}


Table 2. Adsorption-structure characteristics of the adsorbents D1 and DMA responsible for their adsorptive capacity with respect to fluorine

\begin{tabular}{cccccc}
\hline Sample & $\boldsymbol{S}_{\mathbf{s p}}, \mathbf{B E T}, \mathbf{~ m}^{2} / \mathbf{g}$ & Mesopores & Micropores & $\begin{array}{c}\text { Sorption pore } \\
\text { volume } \\
\boldsymbol{V}_{\mathbf{S}}, \mathbf{c m}^{\mathbf{3}} \mathbf{g}\end{array}$ & $\begin{array}{c}\text { Adsorption } \\
\text { capacity* } \\
\mathbf{m m o l} / \mathbf{g}\end{array}$ \\
\hline D1 & 37.54 & 0.032 & 0.012 & 0.0442 & 4.42 \\
DMA & 81.77 & 0.091 & 0.027 & 0.1058 & 8.69 \\
SAS & 183.12 & 0.460 & 0.112 & 0.572 & 8.70 \\
AS as a part of DMA & - & - & - & - & 12.34 \\
\hline
\end{tabular}

*Initial fluorine content was $0.035 \mathrm{~mol} / \mathrm{L}$

The specific surface area of the DMA was $81.8 \mathrm{~m}^{2} / \mathrm{g}$, 2.5 times larger than the corresponding value of the initial diatomite $37.5 \mathrm{~m}^{2} / \mathrm{g}$. The pore blockage and additional micropores introduced by microporous aluminosilicate increased the volume of micropores, thereby increasing the surface area of modified diatomite [11].

\section{ADSORPTION OF FLUORINE ON ALUMINOSILICATE MODIFIED DIATOMITE}

In [12], the authors have been examined the effect of different parameters - solution $\mathrm{pH}$, initial fluorine concentration, sorbent weight, and particle surface charge density to determine the adsorption properties of D1 and DMA with respect to fluorine.

Adsorption experiments have been conducted under batch conditions: $0.2 \mathrm{~g}$ of the adsorbent (D1 or DMA) was introduced into $50 \mathrm{~mL}$ of a sodium fluoride solution in an acetate buffer with an initial fluorine content of $5 \times 10^{-4}$ to $0.3 \mathrm{~mol} / \mathrm{L}$; the mixture was stirred at the speed of $350 \mathrm{rpm}$ for $2 \mathrm{~h}$; this time interval was previously determined as the equilibration time. When the equilibrium achieved, the fluorine concentration was measured using an ELIS 131F fluoride-selective electrode and an I160-M ionometer. Each experiment was conducted twice under identical conditions. The standard deviation of the measurements was within $\pm 3 \%$.

It has been shown that the solution $\mathrm{pH}$ value plays a crucial role in the removal of fluorine from solutions. An efficient removal of fluorine occurs at $\mathrm{pH}$ of 4.5-5.5. Under equilibrium conditions, upon the saturation of the DMA surface with fluorine ions, the adsorption capacity of DMA achieves $58 \mathrm{mmol} / \mathrm{g}$ of sorbent; this value is 5.5 times higher than that of unmodified D1.

Fluorine adsorption isotherms for DMA samples were derived; equilibrium adsorption data were modeled using a two stage Langmuir model; it was shown that the experimental and calculated data on fluorine adsorption were in good agreement: correlation coefficients, $R^{2}$ for D1 and DMA samples were 0.9952 and 0.9687 , respectively.

The fluorine adsorption mechanism has been studied. X-ray diffraction and chemical analyses, FTIR spectroscopy, potentiometric titration, and adsorption-desorption experiments reveal that the DMA- $\mathrm{NaF}-\mathrm{H}_{2} \mathrm{O}$ system is characterized by the occurrence of not only physical adsorption and ion exchange but also the chemical bonding of the fluoride ions with the active sites of the sorbent surface, i.e., the formation of weakly soluble fluorine compounds with $\mathrm{Al}$ on DMA and with $\mathrm{Ca}$ on $\mathrm{D} 1\left(\mathrm{AlF}_{3}, \mathrm{Na}_{3} \mathrm{AlF}_{6}, \mathrm{CaF}_{2}\right)$. It is easy to select two fluorine-aluminum compounds with the lowest solubility aluminum fluoride and cryolite (with negative logarithm of $\mathrm{p} K_{\mathrm{a}}$ of 19.0 and 33.84, respectively) and assume the formation of these compounds on the surface and in the pores of DMA according to the following scheme:

$$
\begin{gathered}
\mathrm{Al}^{3+}+3 \mathrm{~F}^{-} \rightarrow \mathrm{AlF}_{3} \\
\mathrm{AlF}_{3}+\mathrm{NaF} \rightarrow \mathrm{NaAlF}_{4} \\
\mathrm{AlF}_{3}+3 \mathrm{NaF} \rightarrow \mathrm{Na}_{3} \mathrm{AlF}_{6} .
\end{gathered}
$$

At a high level of excess sodium fluoride in the solution, the resulting aluminum fluoride binds $\mathrm{NaF}$ to form a $\mathrm{NaAlF}_{4}$ intermediate 
compound, which transformed into cryolite owing to the further adsorption of $\mathrm{NaF}$.

The data on the composition of D1 (Table 1) suggest that fluorine interacts with calcium, which is in the sample in a significant amount (about $12 \%$ in the form of calcite), to form $\mathrm{CaF}_{2}$ according to the reaction:

$$
\mathrm{Ca}^{2+}(\mathrm{s})+2 \mathrm{~F}^{-}(\mathrm{aq}) \rightarrow \mathrm{CaF}_{2(\mathrm{~s})}
$$

The formation of these compounds proved with FTIR spectra [12].

Table 3 shows changes in the $\mathrm{pH}$ of the samples suspension after 10 min of stirring with water and sodium fluoride solution, as well as in their electro-surface characteristics $\left(\mathrm{pH}_{\mathrm{zpc}}\right)$.

Table 3. Changes in the solution $\mathrm{pH}$ and $\mathrm{pH}_{\mathrm{zpc}}$ during fluorine adsorption by the $\mathrm{D} 1$ and DMA samples

\begin{tabular}{|c|c|c|c|c|}
\hline \multirow[b]{2}{*}{ Sample } & \multicolumn{2}{|c|}{ pH of the suspension after 10 -min stirring } & \multicolumn{2}{|c|}{$\mathrm{pH}_{\mathrm{zpc}}$ of the samples } \\
\hline & $\begin{array}{c}\text { with water, } \\
\mathrm{pH}_{\text {in }} \sim 6.5\end{array}$ & $\begin{array}{c}\text { with a } \mathrm{NaF} \\
\text { solution, } \mathrm{pH}_{\mathrm{in}} \sim 7.2\end{array}$ & $\begin{array}{c}\text { before } \mathrm{F}^{-} \\
\text {adsorption }\end{array}$ & $\begin{array}{c}\text { after } F^{-} \\
\text {adsorption }\end{array}$ \\
\hline D1 & 8.3 & 8.9 & 8.34 & 8.22 \\
\hline DMA & 7.5 & 11.5 & 8.85 & 5.95 \\
\hline
\end{tabular}

\section{RESULS AND DISCUSSION}

The increase in the pore volume of DMA (Table 2) can be ascribed to the blockage of the large mesopores by nanosized aluminosilicate $(25-30 \mathrm{~nm})$ and also by the additional micropores that were brought by the aluminosilicate. It is clear that the adsorption capacity of the sorbent with respect to fluorine depends on the amount and accessibility of $\mathrm{Al}-\mathrm{OH}$ bridges, more readily accessible aluminum ions dissolve much more rapidly and coordinate six $\mathrm{F}^{-}$ions in solution; the more developed the adsorbent pore structure providing a large active surface, the higher the adsorption capacity of the adsorbent, as evidenced by the data in Table 2 .

Besides the blockage of mesopores, changes in the process controlling mechanism may also be connected with the surface hydroxyl groups release into the solution, increasing the solution $\mathrm{pH}$ (Table 2), instead of fluoride ions, which bind to aluminum ions in the mineral lattice, changing the electric surface properties of the latter (Table 3, $\mathrm{pH}_{\mathrm{zpc}}$ value of the samples before and after fluorine adsorption).

Since adsorption involves the sorbatesorbent interfacial interaction, the surface properties of the sorbent play an important role in the sorption process. Once a mineral is brought into a contact with aqueous solution, hydroxyl functional groups $\left(\mathrm{OH}^{-}\right)$are forming on the surface. This is attributed to chemisorption and subsequent hydrolysis of water molecules on the sorbent surface. The surface charge of the sorbent is dependent on the $\mathrm{pH}$ of the surrounding aqueous solution. Neutral or alkaline $\mathrm{pH}$ conditions generally lead to the development of a negative surface charge. Accordingly, under acidic conditions, excess protons are typically retained by the surface, resulting in the development of a total positive surface charge [13]:

$$
\begin{aligned}
& \mathrm{XOH}_{2}^{+} \leftarrow \mathrm{XOH} \rightarrow \mathrm{XO}^{-} . \\
& \text {Low pH High pH }
\end{aligned}
$$

At a certain average $\mathrm{pH}$, which is called the point of zero charge (PZC), the total surface charge is zero:

$$
\left[\mathrm{XOH}_{2}^{+}\right]=\left[\mathrm{XO}^{-}\right] \text {. }
$$

Surface charge can have an effect on the distribution of neighboring solutes in such a way that a decrease in $\mathrm{pH}$ of the surrounding aqueous solution will contribute to the attraction of anionic compounds from the solution to the surface, i.e., to their adsorption [14].

The substitution of aluminum for silicon in the tetrahedral site owing to their different valences, results in a net negative charge due to the charge difference of $\mathrm{SiO}_{4}{ }^{4-}$ and $\mathrm{AlO}_{4}{ }^{5-}$ which is compensated by the introduction of $\mathrm{Na}^{+}, \mathrm{K}^{+}$, $\mathrm{Mg}^{2+}$, or $\mathrm{Ca}^{2+}$ cations (less frequently, $\mathrm{Ba}^{2+}$ and $\mathrm{Li}^{+}$) into the aluminosilicate crystal lattice [15]. An increase in the $\mathrm{Al} / \mathrm{Si}$ ratio leads to a decrease in the aluminosilicate ion sizes and an increase in 
the total negative charge per aluminum atom [16]; as a result, the sorbent surface in solution adsorbs a larger number of protons and the $\mathrm{pH}_{\mathrm{PZC}}$ is shifted to higher values [17] (Table 3).

The fluorine adsorption mechanism can be comprehensively understood if one takes into account the change in $\mathrm{pH}_{\mathrm{PZC}}$ after adsorption. It is known that the formation of inner-sphere complexes (chemisorption) between metal cations located at exchange positions in the sorbent structure and anionic compounds from the solution leads to a shift of the $\mathrm{pH}_{\mathrm{PZC}}$ of the final product to a more acidic range; this fact confirms the formation of some acid groups on the sorbent surface. Specifically adsorbed (chemisorbed) substances contribute to a shift of the $\mathrm{pH}_{\mathrm{PZC}}$ of the adsorbent surface after adsorption. If a cation is chemisorbed, $\mathrm{pH}_{\mathrm{PZC}}$ is shifted to higher values; in the case of chemisorption of an anion, $\mathrm{pH}_{\mathrm{PZC}}$ is shifted to a more acidic region $[18,19]$, see Table 3 .

In Table 2 there are also the data on fluorine adsorption by the initial diatomite D1, DMA, SAS - synthetic aluminosilicate, and the aluminosilicate (AS) grafted on the diatomite surface. One can observe an increase in adsorption capacity of binding aluminosilicate in DMA (AS) compared with the bulk synthetic aluminosilicate (SAS). The AS concentration in DMA is about $53.7 \%$ according to the chemical analysis data with the $\mathrm{Al}_{2} \mathrm{O}_{3} / \mathrm{SiO}_{2}$ ratio $=0.33$. The proportion of adsorption capacity, falling on this amount is $12.34 \mathrm{mmol} \mathrm{F/g}$ of $\mathrm{AS}$, that is 1.3 times higher than that of bulk AS.

To explain this fact, we should examine some reasons: the surface concentration of aluminosilicate in the DMA compound is higher than the bulk content. Therefore, it should be understood that the surface aluminosilicate composition differs with the increased ratio of $\mathrm{Al}_{2} \mathrm{O}_{3} / \mathrm{SiO}_{2}$.

C. Gago et al., when studying the fluorine adsorption on soils, concluded that fluoride adsorption is closely related to the aluminum content in the soil [20]. Takimoto et al. also showed that the adsorption of oxoanions increased with the increase of the aluminum content in the aluminosilicates [21]. They attribute this to the number of highly reactive sites which increased with the increase of $\mathrm{Al}_{2} \mathrm{O}_{3} / \mathrm{SiO}_{2}$ ratio. Since the reactive sites responsible for the adsorption are essentially surface aluminum atoms, it is expected that their concentration is closely associated with the content of $\mathrm{Al}_{2} \mathrm{O}_{3}$ in aluminosilicate being the highest in the compounds with the highest alumina content. Rajan and Perrott (1975) reported that the adsorption of phosphate on silica-alumina gels increased with decreasing $\mathrm{SiO}_{2} / \mathrm{Al}_{2} \mathrm{O}_{3}$ molar ratios [22].

An increase in the aluminum content in the aluminosilicates leads to a higher content of 4-coordinated aluminum [23-25]. Masanori Okazaki et al. [26] have shown that the coordination number of aluminum plays a more important role than the $\mathrm{SiO}_{2} / \mathrm{Al}_{2} \mathrm{O}_{3}$ molar ratio in the adsorption of ions. According to [27], molecular aluminum and silicon precursors are preferentially grafted on sites that enable the formation of $\mathrm{Al}(\mathrm{IV})$. First deposited aluminum species on silica in $\mathrm{Al} / \mathrm{SiO}_{2}$ are $\mathrm{Al}(\mathrm{IV})$ tetrahedrally coordinated species. This specific surface site connectivity eventually enables the formation of Bronsted acid sites. Such acid sites may be formulated as bridging hydroxyls in connection with Al(IV) species, such as pseudobridging silanol in $\mathrm{Al} / \mathrm{SiO}_{2}$, therefore more fluorine is involved in complexes with $\mathrm{Al}$.

\section{CONCLUSIONS}

The diatomite chemically modified with aluminosilicate (DMA) exhibits a considerable increase of its adsorption capacity with respect to fluorine.

The surface-chemical modification of diatomite with aluminosilicate is accompanied with significant changes in its structure and chemical properties - increasing of the ratio of the micro- and mesopores and also the value of the specific surface. The increase in the specific surface area of DMA is connected with both the filling of the large mesopores with aluminosilicate and its own microporous structure.

Partial substitution of $\mathrm{Si}$ atoms in silicates by $\mathrm{Al}$ atoms creates an excess negative charge as a result of their different valences, and $\mathrm{pH}_{\mathrm{PZC}}$ of the sorbent surface shifts to higher values compared to initial diatomite sample that facilitates the attraction of more negatively charged ions from solution.

The surface-chemical modification of diatomite has also a synergetic effect: aluminosilicate in the DMA composition has greater adsorption capacity with respect to fluorine compared to bulk synthetic 
aluminosilicate due to the increased ratio of $\mathrm{Al}_{2} \mathrm{O}_{3} / \mathrm{SiO}_{2}$ and hence to the changes in aluminum coordination in the surface compound in which aluminum is in 4-coordinated form. That plays a major role in enhancing adsorption capacity of the surface aluminosilicate.
The surface layer enriched with the aluminosilicate is more or less uniformly distributed over the pore material surface, so more aluminum sites are accessible for interaction with fluoride ions.

\title{
Вплив мікроструктури модифікованого діатоміту на його адсорбційні властивості
}

\author{
Т.Я. Дацко, В.І. Зеленцов
}

Інститут прикладної фізики Академії наук Молдови

Академічна вул., 5, Кишинів, МД 2028, Республіка Молдова, datsko.tatiana@yandex.ru

Розглянуто вплив змін мікроструктури, викликаних структурно-хімічним модифікуванням діатоміту наночастинками алюмосилікату, на його адсорбиійну здатність щзо до фтору. Показано, що адсорбиійна ємність модифікованого діатоміту перевищує таку для вихідного, необробленого зразка в 5.5 разів: спостерігається свого роду синергізм в адсорбиійних властивостях модифікованого діатоміту: адсорбиійна ємність алюмосилікату, щепленого на поверхню диатоміту, перевищує в 1.3 рази адсорбиійну ємність синтетичного об'ємного алюмосилікату. Обговорюються можливі причини изього явища.

Ключові слова: диатоміт, хімічно-структурна модифікачія, нанорозмірні алюмосилікати, фтор, адсорбиія

\section{Влияние микроструктуры модифицированного диатомита на его адсорбционные свойства}

\section{Т.Я. Дацко, В.И. Зеленцов}

Институт прикладной физики Академии наук Молдовы

Академическая ул., 5, Кишинев, МД 2028, Республика Молдова, datsko.tatiana@yandex.ru

Рассмотрено влияние изменений микроструктуры, вызванных структурно-химическим модифицированием диатомита наночастицами алюмосиликата, на его адсорбичонную способность по отношению к фтору. Показано, что адсорбиионная емкость модифичированного диатомита превышает таковую для исходного, необработанного образия в 5.5 раз: наблюдается своего рода синергизм в адсорбционных свойствах модифицированного диатомита: адсорбционная емкость алюмосиликата, привитого на поверхность диатомита, превьиает в 1.3 раза адсорбционную емкость синтетического объемного алюмосиликата. Обсуждаются возможные причины этого явления.

Ключевые слова: диатомит, химико-структурная модификация, наноразмерный алюмосиликат, фтор, адсорбция 


\section{REFERENCES}

1. Tewari A. and Dubey A. Defluoridation of drinking water: efficacy and need. J. Chem. Pharm. Res. 2009. 1(1): 31.

2. Mahramanlioglu M., Kizilcikli I., Bicer I.O. Adsorption of fluoride from aqueous solution by acid treated spent bleaching earth. J. Fluorine Chem. 2002. 115(1): 41.

3. Fan X., Parker D.J., Smith M.D. Adsorption kinetics of fluoride on low cost materials. Water Res. 2003. 37(20): 4929.

4. Zhang Y., Wang D., Liu B., Gao X., Xu W., Liang P., Xu Y. Adsorption of fluoride from aqueous solution using low-cost bentonite/chitosan beads. American Journal of Analytical Chemistry. 2013. 4(7): 48.

5. Zhang J., Chen N., Tang Z., Yu Y., Hu Q., Feng C. Adsorption of fluoride from aqueous solutions onto Fe-impregnated chitosan and mechamism study. Phys. Chem. Chem. Phys. 2015. 17(18): 12041.

6. Ramos R.L., Turrubiartes J.O., Castillo M.A.S. Adsorption of fluoride from aqueous solution on aluminium-impregnated carbon. Carbon. 1999. 37(4): 609.

7. Tripathy S.S., Raichur A.M. Abatement of fluoride from water using manganese dioxide-coated activated alumina. J. Hazard. Mater. 2008. 153(3): 1043.

8. Zelentsov V.I., Datsko T.Ya., Dvornikova E.E. Fluorine Adsorption by aluminum oxihydrates subjected to thermal treatment. Surf. Eng. Appl. Electrochem. 2008. 44(1): 64.

9. Zelentsov V., Datsko T. Active pore materials based on sludge of $\mathrm{Cr}-\mathrm{Ni}$ alloy electrochemical machining. Moldavian J. Phys. Sci. 2006. 5(2): 162.

10. Zelentsov V., Datsko T., Dvornikova E. Studiul aplicabilitatii diatomitului modificat pentru inlaturarea ionilor de fluor din apele naturale. In: Mediul si Industria, Proc. Int. Symp. (2005, Romania, Bucharest). 1: 213.

11. Datsko T.Ya., Zelentsov V.I., Dvornikova E.E. Physicochemical and adsorption structural properties of diatomite modified with aluminum compounds. Surf. Eng. Appl. Electrochem. 2011. 47(6): 530.

12. Datsko T.Y., Zelentsov V.I. Fluorine sorption by aluminosilicate-modified diatomite from highly concentrated fluorine solutions: 1. Adsorption equilibrium. Surf. Eng. Appl. Electrochem. 2016. 52(3): 300 .

13. Sposito G. The Chemistry of Soils. Second Edition, 7.3. Surface. Charge (Oxford: University Press, 2008).

14. Jara A. A., Goldberg S., Mora M.L. Studies of the surface charge of amorphous aluminosilicates using surface complexation models. J. Colloid Interface Sci. 2005. 292(1): 160.

15. Yuan P., Wu D.Q., He H.P., Lin Z.Y. The hydroxyl species and acid sites on diatomite surface: a combined IR and Raman study. Appl. Surf. Sci. 2004. 227(1-4): 30.

16. Inoue K., Satoh C. Electric charge and surface characteristics of hydroxyaluminosilicate- and hydroxyaluminum-vermiculite complexes. Clays Clay Miner. 1992. 40(3): 314.

17. Tombacz E. pH-dependent surface charging of metal oxides. Chem. Eng. 2009. 53(2):77.

18. James R.O., Parks G.A. Characterization of aqueous colloids by their electrical double-layer and intrinsic surface chemical properties. Surf. Colloid Sci. 1982. 12: 119.

19. Reyes Bahena J.L., Robledo C.A., Lopez V.A, Herrera U.R. Fluoride adsorption onto $\gamma-\mathrm{Al}_{2} \mathrm{O}_{3}$ and its effect on the zeta potential at the alumina-aqueous electrolyte interface. Sep. Sci. Technol. 2002. 37(8): 1973.

20. Gago C., Romar A., Fernandez-Marcos M. L., Alvarez E. Fluoride sorption and desorption on soils located in the surroundings of an aluminium smelter in Galicia (NW Spain). Environmental Earth Sciences. 2014. 72(10): 4105.

21. Takimoto K., Fujita A., Tsuda, S. Adsorption of phosphate on synthetic silica-alumina possessing Lewis-acid sites. Bull Chem. Soc. Jpn. 1977. 50(9): 2479.

22. Rajan S.S.S., Perrott K.W. Phosphate adsorption by synthetic amorphous aluminosilicates. Eur. J. Soil. Sci. 1975. 26(3): 257.

23. Pfleiderer P., Horbach J., Binder K. Structure and transport properties of amorphous aluminium silicates: computer simulation studies. Chem. Geol. 2005. 229(1-3): 1. 
24. Kelsey K., Stebbins J.F., Mosenfelder J.L., Asimow P.D. Simultaneous aluminum, silicon, and sodium coordination changes in $6 \mathrm{GPa}$ sodium aluminosilicate glass. Am. Mineral. 2009. 94(8-9): 1205.

25. Tsomaia N., Brantley S.L., Hamilton J.P., Pantano C.G., Mueller K.T. NMR evidence for formation of octahedral and tetrahedral $\mathrm{Al}$ and repolymerization of the $\mathrm{Si}$ network during dissolution of aluminosilicate glass and crystal. Am. Mineral. 2003. 88(1): 54 .

26. Okazaki M., Kimiwada K., Katsumata H. Adsorption of ions on synthetic amorphous aluminosilicates with different $\mathrm{SiO}_{2} / \mathrm{Al}_{2} \mathrm{O}_{3}$ molar ratios and coordination numbers of aluminum. Soil. Sci. Plant Nutr. 1989. 35(1): 109.

27. Valla M., Rossini A.J., Caillot M., Chizallet C., Raybaud P., Digne M., Chaumonnot A., Lesage A., Emsley L., van Bokhoven J.A., Coperet Ch. Atomic description of the interface between silica and alumina in aluminosilicates through dynamic nuclear polarization surface- enhanced NMR spectroscopy and first-principles calculations. J. Am. Chem. Soc. 2015. 137(33): 10710.

Received 29.07.2016, accepted 06.02.2017 